\title{
COMMERCIALIZATION IN THE SYSTEM OF HIGHER EDUCATION OF EUROPEAN COUNTRIES AND THE USA
}

\author{
КОМЕРЦІАЛІЗАЦІЯ У СИСТЕМІ ВИЩОЇ ОСВІТИ \\ ЄВРОПЕЙСЬКИХ КРАЇН ТА США
}

\begin{abstract}
The article deals with the analysis of the commercialization in the system of higher education of European countries and the USA. It is noted that if European systems of higher education are characterized by tendencies to international cooperation, internationalization of education and the desire to create a single European educational space, whereas for American and higher education systems similar to it, the determining factors are not cultural factors, but economic ones. It is mentioned that massification and especially commercialization of education are quite dangerous for the classical institution of education.

In a number of European countries there is an extraordinary diversity of higher education institutions, but there is a similarity in the development of higher education systems in general. Among the general indicators, in particular, can be called: decentralization, academic autonomy, public responsibility for the system of higher education, public funding of higher education, internationalization and so on.
\end{abstract}

In general, the above mentioned analysis of the systems and models of higher education suggests the extraordinary scale of commercialization in an open form, providing for both positive and negative trends and, in turn, leading to the modernization and transformation of educational institutions. It is determined that the functional purpose of entering into a single world educational space is to confront the growing trends of americanization and commercialization, the spread of which is ambiguously assessed in Europe. It is determined that the functional purpose of entering into a single world educational space is to confront the growing trends of americanization and commercialization, the spread of which is ambiguously assessed in Europe. The consideration of higher education in the American model not as a social institution, but as a commercial industry is determined by the existence of a multi-University, "Academic capitalism", "Market-type University" and "the Entrepreneurial University", which have a significant impact on the development of the educational system as a whole.

Key words: higher education, University, the Entrepreneurial University, paradigm, transformation.

у статті здійснено аналіз комериіалізації у системі вищої освіти європейських країн та США. Зазначається, що для європейських систем вищої освіти характерні тен- денції до міжнародного співробітництва, інтернаціоналізації освіти та прагнення до створення єдиного європейського освітнього простору, тоді як для американської та подібних до неї систем вищої освіти визначальними є не культурні фрактори, а економічні.

Визначено, що масовість і особливо комерціалізація освіти $\epsilon$ досить небезпечними для класичного навчального закладу. Незважаючи на те, що сьогодні в Європі усе більше починає відчуватися американський вплив як культури, так і вищої освіти, зокрема, багатовікове лідерство німецької, англійської, орранцузької вищої освіти знаходить своє підтвердження в сучасних загальноєвропейських тенденціях розвитку освіти. Це і дає можливість приділити їм більшу увагу під час проведення компаративного аналізу європейських систем вищої освіти. У низці європейських країн спостерігається надзвичайна різноманіт ність вищих навчальних закладів, проте відзначається схожість тенденцій у розвитку систем вищої освіти у цілому. Серед спільних показників, зокрема, можна назвати: децентралізацію, академічну автономію, державну відповідальність за систему вищої освіти, державне фрінансування вищої освіти, інтернаціоналізацію тощо.

Вищенаведений аналіз систем та моделей вищої освіти дозволяє говорити про надзвичайні масштаби комерціалізації у відкритій формі, передбачаючи як позитивні, так і негативні тендениії та, у свою чергу, призводячи до модернізації і транссрормації інститутів освіти. Визначено, що функціональним призначенням входження до єдиного світового освітнього простору постає протистояння зростаючим тенденціям американізації та комерціалізації, поширення яких неоднозначно оцінюють у Європі. Розгляд вищої освіти в американській моделі не як соціального інституту, а як комерційної індустрії визначається існуванням мультиверситету, «академічного капіталізму», «університету ринкового типу» та «підприємницького університету», які мають вагомий вплив на розвиток освітньої системи в цілому.

Ключові слова: вища освіта, університет, комерціалізація, освітній простір, трансформація.
The undermined scientific problem of the article. According to the French sociologist J. Baudrillard, consumerism in the modern world turns into certain dependence, and thus oniomania develops. For such individuals, goods lose their importance and are gradually turning into the symbol of affiliation with a certain social medium, a group etc., and consumption is gradually turning into the sense of life. Taking into consideration the mentioned conditions, in the society of consumption education and knowledge obtainment constitute a certain advertised and informationally formatted product that requires involvement of managers and marketologists in 
its selling, performing advertisement actions and campaigns.

However, massification and especially commercialization of education are quite dangerous for the classical institution of education. Whereas education as another global commercial trend threatens the very institutional foundations and its contents. P. Altbach, director of the Center for International Higher Education at Boston College, admits it and mentions that higher education is being more and more frequently studied as goods that can be sold and bought the same way as any other goods. Nowadays, commercialization of this sphere is reaching the level of global market. Indeed, the World Trade Organization (WTO) is already considering the issue of inclusion of higher education in the sphere of its interests; as a result, import and export of educational services might become the subject of the sophisticated procedures of the organization and legal regulation of its decisions. Thus, within the unified transnational system of education, the key role will be played by more financially provided educational institutions. If the similar phenomenon occurs, higher education in all its manifestations will become the object of free trade rules [1].

Analysis of the latest research and publications. Modern development of foreign education sociology is described in papers by M. Archer, J. Beaulieu, R. Boudon, J. Coleman, N. Luhmann, J. Meyer, J. Passeron. The authors mentioned consider the education system within the context of its socio-typological, morphogenetic, functional-systemic specific features, as an instrument of establishing distinctions (discernings), communication, gabitualization. All the processes mentioned are inherent in the system of education of both institutionalized and non-institutionalized forms. Institutionalization of the education system is accompanied by its establishment as a completely autonomous system able to develop following on from the limited interference of other social subsystems with its operation [7;9].

Presentation of the main material of the study and the substitution of the obtained scientific results. P. Altbach in his paper 'Higher Education in the World' claims that, in accordance with their origin, universities stimulate local economy [1]. Any university creates economic benefits for its community through local purchases, real estate investments and expenses of students and teaching staff. Since Humboldtian reforms in Germany, an increase of the number of 'grants' at the universities in the USA and appearance of Japanese imperial universities in the 19th century, universities have been created for providing the contribution into economic development. Universities support knowledge and technologies on the basis of the fields that use knowledge accumulated at establishments including graduates' skills. Universities have made their contribution into this development through creating science parks and even investing in companies that use universities on the basis of knowledge.

The American sociologist J. Bloom claims that for the past several decades one of the disputable issues regarding higher education has been the idea of recognizing education as a social good (adding value to society, teaching its citizens) or a private good (aimed at gaining money and satisfaction from getting privileges as a result of education obtainment). The logics of discussion dictates that if higher education is a private good, then those getting benefits from it - i.e. students must pay. If higher education is primarily a social good, then society is obliged to provide support.

Generally, for the past decades the cost of higher education services has increased. Requirements of mass access in combination with increasing expenses on scientific research universities exert bigger pressure on the states to provide financing. That is why state bodies in many countries have shifted financial responsibility for higher education on the 'users', i.e. students and their families. In several cases, credits and other financing programmes have been introduced.

One of the issues with the modern accent on a private good constitutes the fact that research universities are state establishments. Within the long-term perspective, fundamental research, for example, might lead to commercially valuable products, but the research itself usually brings little income. Fundamental research is a social good, and thus it requires support. Research universities are in the need of main research infrastructure, including talented (and often highly-paid) professors, modern laboratories and other objects, as well as PhD students. Moreover, many services provided by research universities are non-commercial. Research universities asked to commercialize their scientific research and other events. Thus, mass higher education is designed for providing access for students from all social classes. The idea of a social good as a key factor of higher education support is directly connected with the role academic institutions might play in the society. Operation of higher educational institutions - from cultural and information-enlightening activities to fundamental research - is directly connected with the social good.

It is worth mentioning that private higher school is quickly spreading in many parts of the world and is currently enrolling more than a half of all students in most Latin American and other countries. Except for several training establishments in the USA and Japan, private training institutions are usually not prestigious, have restricted objectives and programmes, depend on exclusively income obtainment for the sake of survival. Most of them are formal or informal commercial schools. Private sector in higher education is defined as a 
private good whose students anticipate career progress. Privatization of state higher education contributed to narrowing the role of universities. In many countries, state universities are getting now a smaller part of their budgets from state sources. As a result, they are to have their own income from tuition fees, research, consulting, commercial enterprises and other sources [10].

All the above mentioned challenges are connected with the requirements of the market regarding universities. However, this tendency creates a huge contradiction between new accents and the role universities have been playing during the past century concerning providing the increasing number of students with the access to higher education. More sophisticated goals require bigger and more complicated academic institutions. In 1963, C. Kerr noticed that universities need bigger and more complicated administration and management structures to perform all of their new roles. This need is a requirement of higher responsibility - concerning not only money spending, but also fulfilling many aspects of the training enterprise including performance of students and efficiency of faculty members. Traditional academic administrations that generally take major decisions do not operate well within the large, sophisticated establishments of the 21st century. Universities are in the need of administrative structures able to coordinate different elements of the institution and to carefully define and measure resources.

Particularly, not farther than three decades ago American sociologists A. Toffler and D. Bell admitted that education and knowledge are strategic resources of the epoch of postindustrialism [4]. At the same time, the expression of F. Bacon 'knowledge is power' gets confirmed. It is not a surprise, that these are intellectuals who constitute the dominant part of the richest Americans. Just each fifteenth of those constituting the $1 \%$ of the richest Americans have obtained income as capital gain, while more than a half of representatives of the group occupy administrative positions at big companies, about one third is represented by practicing doctors and lawyers, and the other third contains people of creative professions including professors and lecturers'. Considering the fact that $1 \%$ of Americans possess $80 \%$ of wealth in the United States, the above mentioned figures unambiguously show that power in the USA (and thus in the whole world) belongs to those who develop and use their intellect in the goal-rational way.

It is necessary to mention that technically commercialization has performed a drastic fall of prestige of science and the system of education. Nowadays, thousands of different 'pseudouniversities' have been established on the basis of small private enterprises and social organizations. Finally, the current reform of higher educa- tion presupposes strict compliance of universities (educational cycles, their contents, duration etc.) with requirements of big business as a source of working places. All these processes support the logics of 'diploma depreciation' described by the American sociologist $R$. Collins already 30 years ago. Higher education diploma turns from the certificate of high intellectual merits and the social status of a person into a plain card certifying minimal social competence - like a passport or driving licence [8]. Conceptually, commercialization is optimized for the growth potential of this sector. Taking into account all the above mentioned conditions, one might claim that commercialization of the system of education is a peculiar trend of the consumption society which introduction must be maintained with caution and prudence for the sake of preserving traditional values of the system of education.

Furthermore, it is worth noticing, that commercialization is one of the tendencies of education system change. By the end of the past century, there had developed a whole field of the world economy - i.e. the international market of educational services with annual volume of sales of about several tens of billions dollars and the number of consumers of about several millions of students. Obtainment of higher education by foreign students has become a new field of export. According to estimations by the World Trade Organization, the volume of the world education market is $50-60$ billion dollars. The stable leader is the USA controlling almost the one fourth of the world financial educational turnover. The second place is occupied by Great Britain - 15\%. They are followed by Germany - 12\%, France - 9\%, Australia, Canada, Spain - 7\% .

It is necessary to note that internationalization that is changing the essence and the internal side of higher education develops in the direction of international activity. Under such conditions, state, market and university preserve their institutional specific features, though actually they compete with one another. Under multicultural conditions, internationalization presupposes interaction between universities and educational systems. Therefore, internationalization changes the educational space, and globalization hereby changes the world where internationalization develops. Under such conditions, as Z. Bauman and P. Scott mention, higher education undertakes flexibility and even becomes deinstitutional $[3 ; 10]$. It is worth mentioning that the market of educational services is seeng the emergence of distance and virtual education. Distance education develops within both universities, colleges and new completely virtual educational establishments which do not presume material existence of a university campus. The market of virtual education is shaping with the key role being played by commercial structures, communication and 
multimedia companies. Higher education sees foundation of its own powerful transnational corporations, new kinds of partnership, coalitions and alliances. Classical higher educational institutions begin to share their functions with myriads of unions and partners both within the system of education and beyond it. Definitely, it contributes to the emergence of diverse problems including the problems of higher education quality and accessibility. On the other hand, modern processes of higher education diversification confirm once more the complication of sociocultural medium. Hence, traditional universities have to adapt to the new sociocultural reality that requires drastic transformations.

Hence, knowledge in the modern society plays a role of the major economic resource, and it does not raise any doubts. Nevertheless, the main task lies in development of higher education and prediction of the major directions of knowledge which will be popular on the labor market in several years.

Generally, the era of globalization, informatization and mass consumption drastically influences the development of education institutions. Furthermore, the past decades are characterized by modernization of the whole society and higher education oriented at development of market relations. Strengthening of commercialization in the educational sphere is a problem of the present. Whereas reforms of higher education have resulted in a certain medium of commercial education that requires the existence of new rules of interaction, status-role interrelations, value-normative formations. Commercialization is actually a certain challenge of the present; nevertheless, society sees scientific disputes concerning the scale of this process, its form and the way it affects the quality of providing educational services. In modern Europe, there exist different systems and models of higher education that, on one hand, constitute the major representation of the national cultures of European countries and, on the other hand. Thus, one should study in more details the way commercialization emerges in the European and American educational models.

Regardless of the fact that in Europe today the American influence of both culture and higher education in particular is becoming more and more tangible, the longstanding leadership of German, English, French higher education finds its confirmation in modern all-European tendencies of education development. It provides the opportunity to pay more attention to them when conducting comparative analysis of European systems of higher education.

The range of European countries experience extraordinary diversity of higher educational institutions, but the tendencies of higher education system development are generally similar. Among the above mentioned indeces, one should point out the following: decentralization, academic autonomy, state responsibility for the system of higher education, state financing of higher education, internationalization etc. European higher education possesses certain distinctness that makes it different from the American model, regardless of the fact that in modern Europe there is a diversity of educational systems with their own traditions, training models and scientific schools.

Under the conditions of formation of unified values, the European system of higher education longs for preserving its diversity and at the same time for responding to modern challenges of globalization that finds its reflection in aspiration for reviving internationalization traditions. Joining the united global educational space is one of the directions of development of the European higher education international connections; its functional purpose consists in resisting the increasing tendencies of Americanization and commercialization which expansion in Europe is evaluated controversially. Nevertheless, development of Ukrainian educational traditions has been developed under the influence of the European.

Conclusions. In response to decrease of state financing and extension of the borders of the global market of educational services, modern universities are increasingly becoming active subjects of the market, and that defines the institutional changes of higher education, trasnformation of universities from centers of liberal education into enterprises producing knowledge and educational services. For the past years, higher education in the American model is considered not as a social institution, but a commercial industry. Whereas social institutions, traditionally including higher education, have their own logics of normative requirements, a system of status-role relations, perform particular functions (contribute into not only students' training, but their upbringing, shaping of the system of moral and aesthetic norms, civil responsibility), the system of industry presupposes performance of other tasks.

University fulfills its aim regarding preparation of students to successful actions on the labor market under the conditions of intense competition and to upgrade of their image on the market of educational services. Transition to the market orientation of higher education leads to unpredictable consequences for both students, universities and society as a whole.

Under the conditions of postindustrial society, the American sociologist D. Bell admitted that universities cover many functions in the sphere of scientific research and provision of needs in highly-qualified staff, in general development of education. The University was proclaimed the center of establishment culture. 


\section{ГАБІТУС}

Development of the global market of educational services and management in universities have lead to institutional changes in the system of higher education. As an example we may study an American university managed by legislators, economic and political leaders of the society where private universities are controlled by political councils.

\section{REFERENCES:}

1. Альтбах Ф. Г. Высшее образование и WTO: безумие глобализации. Alma Mater. Вестник высшей школы. 2001. № 6. С. 39-42.

2. Бауман 3. Глобализация. Последствия для человека и общества. Москва: Весь мир, 2004. 188 с.

3. Бауман 3. Образование - при, для и несмотря на постмодернити. Индивидуализированное общество / Под ред. В.И. Иноземцева. Москва : Логос, 2002. C. 155-175.
4. Белл Д. Грядущее постиндустриальное общество. Опыт социального прогнозирования. Москва : Academia, 1999. 956 c.

5. Кун Т. Структура научных революций. Москва : Прогресс, 1975. 256 с.

6. Archer M. Social Origins of Educational Systems. New York : IA Books, 2007. 215 p.

7. Archer M. Sociology of Educational Development. London : Sage, 1979. 156 p.

8. Collins English Dictionary. URL : www. collinsdictionary.com/dictionary/english.

9. Luhmann N. Das Erziehungssystem der Gesellschaft. F/M., 2002. 157 p.

10. Scott P. The Crisis of the University. London : Sydney Croom Helm, 1984. 277 p.

11. Sociology of Education / Eds. D. Levinson, H. Cookson, A. Sadovnik. New York : Routledge-Faimer, 2002. $234 \mathrm{p}$.

12. Spring J. Globalization of Education. GB., 2014. 211 p. 